\title{
GCU
}

Glasgow Caledonian

University

University for the Common Good

\section{Top 10 research priorities relating to stroke nursing}

Pollock, Alex; St. George, Bridget; Rowat, Anne

Published in:

International Journal of Stroke

DOI:

10.1111/ijs. 12601

Publication date:

2015

Document Version

Author accepted manuscript

Link to publication in ResearchOnline

Citation for published version (Harvard):

Pollock, A, St. George, B \& Rowat, A 2015, 'Top 10 research priorities relating to stroke nursing', International Journal of Stroke, vol. 10, no. A100, pp. 164. https://doi.org/10.1111/ijs.12601

\section{General rights}

Copyright and moral rights for the publications made accessible in the public portal are retained by the authors and/or other copyright owners and it is a condition of accessing publications that users recognise and abide by the legal requirements associated with these rights.

Take down policy

If you believe that this document breaches copyright please view our takedown policy at https://edshare.gcu.ac.uk/id/eprint/5179 for details of how to contact us. 
TITLE: Top Ten research priorities relating to stroke nursing

\section{AUTHORS:}

Alex Pollock (PhD), Nursing Midwifery and Allied Health Professions (NMAHP)

Research Unit, Buchanan House, Glasgow Caledonian University, Glasgow G4 0BA, United Kingdom

Bridget St George (MSc Nursing), Nursing Midwifery and Allied Health Professions (NMAHP) Research Unit, Buchanan House, Glasgow Caledonian University, Glasgow G4 OBA, United Kingdom

Anne Rowat (PhD), Edinburgh Napier University, Sighthill Campus, Edinburgh EH11 4BN, United Kingdom

On behalf of the Scottish Stroke Nurses Forum (SSNF)

\section{CORRESPONDENCE:}

Dr Alex Pollock

NMAHP Research Unit

Buchanan House

Glasgow Caledonian University

Glasgow G4 0BA

Scotland, UK

Email: alex.pollock@gcu.ac.uk

Tel: (+44) 1413318100

Key words: stroke, nursing, prioritization, research priority

Word count: 223 (main text only)(496 including text, table, references, acknowledgements)

Conflicts of interest: none declared 


\section{Top ten research priorities relating to stroke nursing}

\section{Dear Editor}

In April 2014 you published the top ten priorities relating to life after stroke (1) and encouraged your readers to think more broadly about stroke research priorities (2). This research prioritisation project established 226 unique unanswered research questions, through stakeholder involvement, before completing (i) an interim prioritisation stage and (ii) a final consensus meeting to reach agreement on the shared top ten research priorities. We have now repeated these two stages, using the 226 previously identified questions, in order to identify the priorities which stroke nurses consider to be of greatest importance for nurse-led stroke research.

Ninety-seven nurses, working in stroke care in Scotland, participated in the interim prioritisation stage, leading to the identification of 28 shared top priorities. At a final consensus meeting 27 purposively selected nurses agreed their Top Ten priorities for stroke nursing research (see Table).

It is important to build research capability and capacity of stroke nurses, and supporting meaningful and useful nurse-led research is a key way of achieving this (3). The previously published top ten research priorities do not afford direction to any one professional group. We have now defined the research agenda for stroke nursing, adopting a pragmatic and efficient approach, which built on the previouslycompleted prioritisation project (1). We urge nurses and nursing-oriented research organisations to establish collaborative activities to address these priorities. 


\section{REFERENCES}

1. Pollock A, St George B, Fenton M, Firkins L. Top ten research priorities relating to life after stroke - consensus from stroke survivors, caregivers and health professionals. International Journal of Stroke. 2014;9(3):313-20

2. Donnan GA. Research priorities. International Journal of Stroke. 2014;9(3):259

3. SSNF. Scottish Stroke Nurses Forum. http://www.chss.org.uk/healthprofessionals/professional-forums-groups/scottish-stroke-nurses-forum-ssnf/ (last accessed 29 $9^{\text {th }}$ April 2015) 


\begin{tabular}{|c|c|}
\hline Number & Research priorities relating to stroke nursing: \\
\hline 1 & What are the best ways to manage and/or prevent fatigue? \\
\hline 2 & What are the best ways to improve cognition after stroke? \\
\hline 3 & What are the best ways to manage urinary and faecal incontinence? \\
\hline 4 & What are the best ways to manage altered mood and emotion after stroke? \\
\hline 5 & What are the best ways to promote self-management and self-help after stroke? \\
\hline 6 & $\begin{array}{l}\text { What are the best ways of helping stroke survivors and their families come to terms } \\
\text { with uncertainty of prognosis and the long term consequences of stroke? }\end{array}$ \\
\hline 7 & Can a goal setting approach help recovery after stroke? \\
\hline 8 & What is the impact of thrombolysis on emotion, cognition and communication? \\
\hline 9 & $\begin{array}{l}\text { Is a "young stroke environment" better than other stroke rehabilitation environments at } \\
\text { improving recovery of young people after stroke? }\end{array}$ \\
\hline 10 & $\begin{array}{l}\text { What is the optimal amount and intensity of therapy provided by nurses for patients } \\
\text { with stroke? }\end{array}$ \\
\hline
\end{tabular}

TABLE: Top Ten research priorities relating to stroke nursing 


\section{Acknowledgements}

This priority setting project was supported by funding from Chest Heart and Stroke Scotland (CHSS). The Nursing Midwifery and Allied Health Professions (NMAHP) Research Unit is supported by the Scottish Government Health Directorate's Chief Scientist Office. The work presented here represents the views of the authors and not necessarily those of the funding bodies. 